\title{
Endopolyploidy in Bryophytes: Widespread in Mosses and Absent in Liverworts
}

\author{
Jillian D. Bainard and Steven G. Newmaster \\ Department of Integrative Biology, University of Guelph, Guelph, ON, Canada N1G 2W1 \\ Correspondence should be addressed to Jillian D. Bainard, jbainard@uoguelph.ca
}

Received 1 March 2010; Accepted 30 April 2010

Academic Editor: Johann Greilhuber

Copyright ( $\odot 2010$ J. D. Bainard and S. G. Newmaster. This is an open access article distributed under the Creative Commons Attribution License, which permits unrestricted use, distribution, and reproduction in any medium, provided the original work is properly cited.

\begin{abstract}
Endopolyploidy occurs when DNA replication is not followed by mitotic nuclear division, resulting in tissues or organisms with nuclei of varying ploidy levels. Endopolyploidy appears to be a common phenomenon in plants, though the prevalence of endopolyploidy has not been determined in bryophytes (including mosses and liverworts). Forty moss species and six liverwort species were analyzed for the degree of endopolyploidy using flow cytometry. Nuclei were extracted in LB01 buffer and stained with propidium iodide. Of the forty moss species, all exhibited endopolyploid nuclei (mean cycle value $=0.65 \pm 0.038$ ) except for the Sphagnum mosses (mean cycle value $=0$ ). None of the liverwort species had endopolyploid nuclei (mean cycle value $=0.04 \pm 0.014)$. As bryophytes form a paraphyletic grade leading to the tracheophytes, understanding the prevalence and role of endopolyploidy in this group is important.
\end{abstract}

\section{Introduction}

Polysomaty is the occurrence of nuclei of varying ploidy levels in the same individual, often associated with different cell or tissue types. This condition of nuclei of varying ploidy levels, known as endopolyploidy, is a result of endoreduplication, which occurs when DNA replication is not followed by mitosis. The mechanisms behind endoreduplication are suggested to involve changes in the activity of cyclindependent kinases, which affect the normal transition of the cell cycle [1]. There is, however, a lack of knowledge and understanding regarding the extent, role, and control of endopolyploidy in plants [2].

Various hypotheses have been suggested to explain the importance of endopolyploidy, including growth, development, and stress response [1,3-5]. One suggested role of endopolyploidy relates directly to the "Nucleotypic Theory," which states that DNA content directly impacts cell volume and other phenotypic traits, which in turn affects various aspects of organism form and function [6,7]. Barow and Meister [8] and Jovtchev et al. [9] have produced evidence to support this hypothesis, finding that endopolyploidy can allow plants with small genomes to have increased nuclear and cell volume to assist in growth and development. In turn, endopolyploidy is correlated with life history strategy and phylogenetic affiliation [8] and is influenced by various environmental factors including temperature $[10,11]$, light [12], drought [13], and salinity [14].

Among land plants, endopolyploidy is common in angiosperms but appears to be rare in gymnosperms and ferns [15]. According to a summary completed in 2007, out of thirty explored angiosperm families, nineteen families contain species that predominantly exhibit endopolyploidy [16]. Endopolyploidy occurs in various algal groups [17-19], but in gymnosperms, endopolyploidy is scarce $[8,20]$, and in ferns there are only isolated references [21-23].

In bryophytes (broadly referring to mosses, liverworts and hornworts), the frequency of endopolyploidy is not known, though some studies present data on specific species or specifically targeted tissues. These studies include the presence of endopolyploidy in polytrichaceous mosses including food-conducting cells [24] and mucilaginous hairs and parenchyma [25], and endopolyploid caulonema in Funaria hygrometrica $[26,27]$. Endopolyploidy has also been 


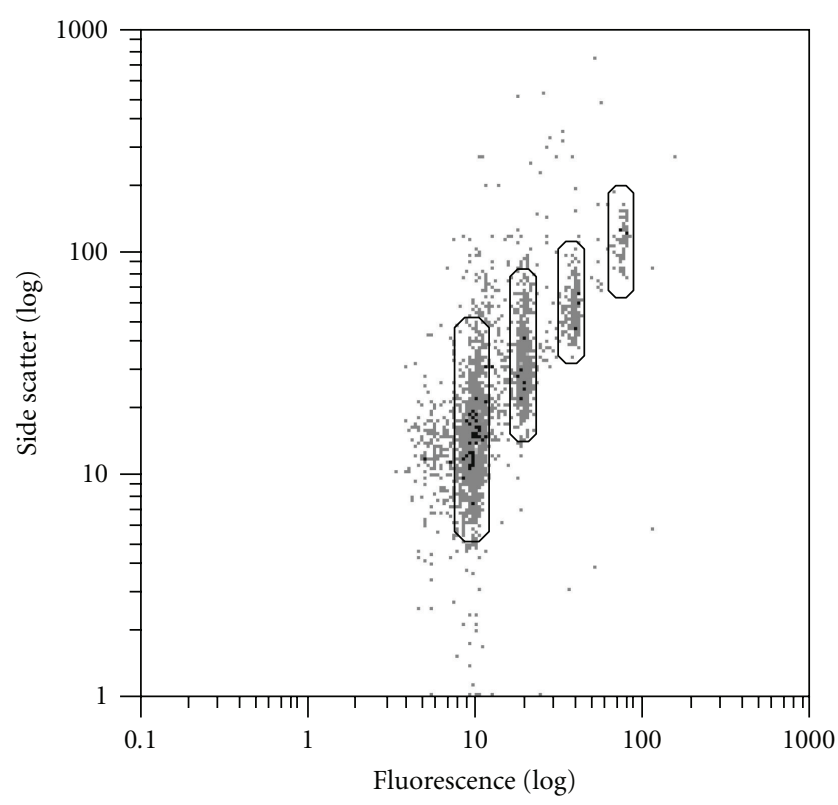

(a)

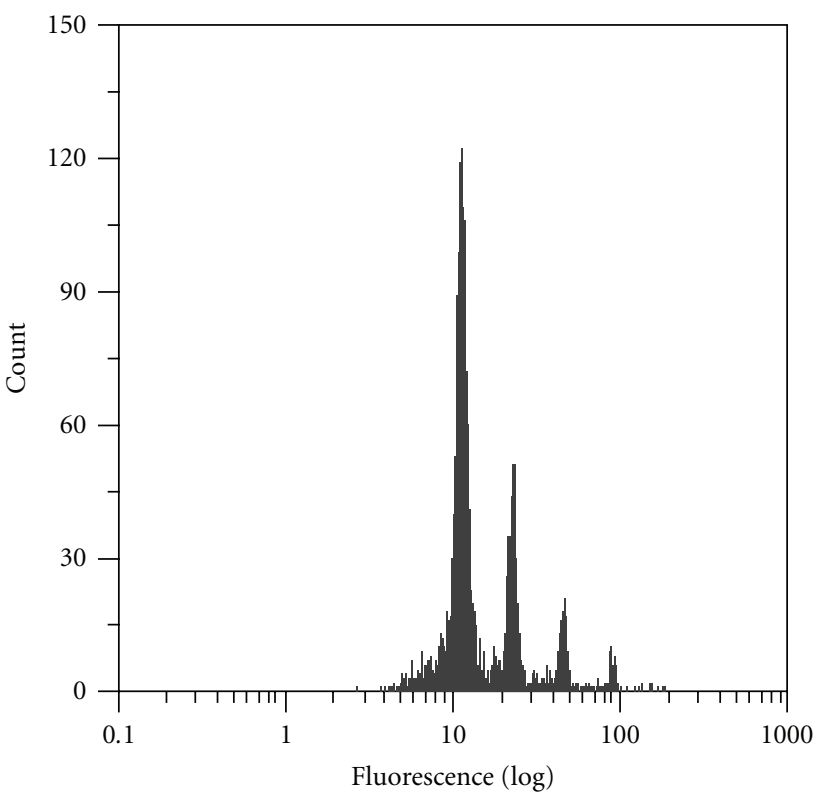

(b)

Figure 1: Determination of endopolyploidy in Rhytidiadelphus triquetrus using flow cytometry. (a) Scattergram of side scatter versus fluorescence with polygon gates. (b) Histogram of counts versus fluorescence.

observed in moss rhizoids and food conducting tissues [28]. The use of flow cytometry to observe endopolyploidy in bryophytes has been referred to anecdotally [29]. Additionally, endopolyploidy has been explored in the model moss, Physcomitrella patens, which has a unique case of exhibiting two distinct ploidy levels in different tissues. Chloronema cells were found to have predominantly $2 \mathrm{C}$ or G2 nuclei, while the caulonema nuclei were $1 \mathrm{C}$ [30]. In an initial assessment of the $P$. patens genome, there were so few nuclei in the $1 \mathrm{C}$ phase; the $2 \mathrm{C}$ peak was mistakenly identified as the 1C peak [31]. Treatment of $P$. patens with auxin resulted in an increase in $1 \mathrm{C}$ nuclei and also an increase in $4 \mathrm{C}$ nuclei [32]. Older caulonema cells also had a higher degree of endopolyploidy [33].

As bryophytes represent the earliest plants to inhabit terrestrial ecosystems [34], the role of endopolyploidy in this group of organisms is relevant in order to increase our understanding of the evolution of endopolyploidy. Bryophytes have small genome sizes [35] and exhibit unique life history strategies $[36,37]$ as well as habitat specificity $[38,39]$. Flow cytometry provides an efficient way to observe endopolyploidy over a range of specimens. These factors make bryophytes ideal organisms to explore the prevalence, role, and biological significance of endopolyploidy. The objective of the present study is to provide the first survey of the prevalence of endopolyploidy in bryophytes.

\section{Materials and Methods}

Bryophyte specimens were collected in Ontario, Canada, in the summer of 2009. Forty moss species representing seventeen families and six liverwort species from five families were collected (see Table 1). Voucher specimens are deposited in the Biodiversity Institute of Ontario Herbarium $(\mathrm{OAC} / \mathrm{BIO})$, University of Guelph. From each population, three independent replicates were analyzed on separate days using flow cytometry, except for three of the liverwort species, where there was insufficient tissue. The samples were composed of green shoots, which included both stem and leaf material. General methodology followed Galbraith et al. [40] and Doležel et al. [41] and was refined according to Bainard et al. [42]. Approximately $10 \mathrm{mg}$ of air-dried bryophyte tissue was chopped in $1.2 \mathrm{ml}$ cold LB01 buffer and the resulting solution was filtered through a $30 \mu \mathrm{m}$ mesh. The nuclei were stained with $150 \mu \mathrm{g} \mathrm{ml}^{-1}$ propidium iodide (Sigma) in the presence of $0.5 \mu \mathrm{g} \mathrm{ml}^{-1}$ RNase A (Sigma). Samples were incubated on ice for 20 minutes. For each sample, at least 1000 nuclei were analyzed.

Flow cytometric analysis was completed on a Partec CyFlow SL (Partec GmbH, Münster, Germany) equipped with a blue solid-state laser tuned at $20 \mathrm{~mW}$ and operating at $488 \mathrm{~nm}$. Before each use, the instrument was calibrated using $3 \mu \mathrm{m}$ calibration beads (Partec, Münster, Germany). The parameters recorded for each bryophyte sample included fluorescence intensity at $630 \mathrm{~nm}$ measured on a log scale, forward scatter and side scatter. These parameters were observed alone and in combined scattergrams including: fluorescence versus side scatter and fluorescence versus forward scatter.

To determine the degree of endopolyploidy, the number of nuclei (n) in each ploidy level was counted, using FloMax Software by Partec (Version 2.52, 2007). Due to the interference of debris particles, polygon gates were drawn around the nuclei of interest on the fluorescence versus side scatter scattergram to determine the number of nuclei in each peak (Figure 1). To quantify the degree of endopolyploidy, the cycle value was calculated, which is a measure of the number 
TABLE 1: Degree of endopolyploidization of forty moss species and six liverwort species. Mean cycle value and mean $C$-level results are based on three replicates except where noted.

\begin{tabular}{|c|c|c|c|}
\hline Family & Species & Mean Cycle Value \pm Standard Error & Mean $C$-level \pm Standard Error \\
\hline \multicolumn{4}{|l|}{ Mosses } \\
\hline \multirow[t]{2}{*}{ Sphagnaceae } & Sphagnum angustifolium & $0.00 \pm 0.000$ & $1.00 \pm 0.000$ \\
\hline & Sphagnum recurvum & $0.00 \pm 0.000$ & $1.00 \pm 0.000$ \\
\hline \multirow[t]{2}{*}{ Polytrichaceae } & Polytrichum commune & $0.33 \pm 0.055$ & $1.39 \pm 0.068$ \\
\hline & Polytrichum juniperum & $0.60 \pm 0.060$ & $1.80 \pm 0.090$ \\
\hline Fissidentaceae & Fissidens taxifolius & $0.40 \pm 0.039$ & $1.48 \pm 0.056$ \\
\hline \multirow[t]{7}{*}{ Dicranaceae } & Dicranum condensatum & $0.87 \pm 0.072$ & $2.17 \pm 0.148$ \\
\hline & Dicranum flagellare & $0.50 \pm 0.015$ & $1.62 \pm 0.022$ \\
\hline & Dicranum fuscescens & $0.57 \pm 0.087$ & $1.75 \pm 0.125$ \\
\hline & Dicranum montanum & $0.52 \pm 0.029$ & $1.63 \pm 0.041$ \\
\hline & Dicranum polysetum & $1.11 \pm 0.030$ & $2.34 \pm 0.049$ \\
\hline & Dicranum scoparium & $0.98 \pm 0.048$ & $2.17 \pm 0.101$ \\
\hline & Trematodon ambigus & $0.51 \pm 0.055$ & $1.62 \pm 0.063$ \\
\hline Ditrichaceae & Ceratodon purpureus & $0.51 \pm 0.060$ & $1.73 \pm 0.067$ \\
\hline Orthotrichaceae & Orthotrichum speciosum & $0.29 \pm 0.071$ & $1.40 \pm 0.114$ \\
\hline Hedwigiaceae & Hedwigia ciliata & $0.34 \pm 0.030$ & $1.51 \pm 0.056$ \\
\hline Aulacomniaceae & Aulacomnium androgynum & $0.64 \pm 0.076$ & $1.91 \pm 0.092$ \\
\hline \multirow[t]{3}{*}{ Mniaceae } & Plagiomnium drummondii & $1.37 \pm 0.054$ & $2.91 \pm 0.105$ \\
\hline & Plagiomnium medium & $1.21 \pm 0.152$ & $2.81 \pm 0.353$ \\
\hline & Pohlia whalenbergia & $1.13 \pm 0.125$ & $3.33 \pm 0.282$ \\
\hline \multirow[t]{3}{*}{ Hylocomiaceae } & Hylocomnium splendens & $0.53 \pm 0.165$ & $1.71 \pm 0.253$ \\
\hline & Pleurozium schreberi & $0.35 \pm 0.079$ & $1.42 \pm 0.098$ \\
\hline & Rhytidiadelphus triquetrus & $0.52 \pm 0.036$ & $1.75 \pm 0.069$ \\
\hline Leskeaceae & Haplocladium microphyllum & $0.41 \pm 0.086$ & $1.55 \pm 0.117$ \\
\hline \multirow[t]{2}{*}{ Thuidiaceae } & Thuidium delicatulum & $0.91 \pm 0.119$ & $2.30 \pm 0.184$ \\
\hline & Thuidium minulatum & $0.41 \pm 0.025$ & $1.52 \pm 0.032$ \\
\hline Campyliaceae & Campylium chrysophyllum & $0.64 \pm 0.057$ & $1.77 \pm 0.077$ \\
\hline \multirow[t]{4}{*}{ Brachytheciaceae } & Brachythecium acuminatum & $0.54 \pm 0.045$ & $1.65 \pm 0.049$ \\
\hline & Brachythecium salebrosum & $0.14 \pm 0.018$ & $1.16 \pm 0.023$ \\
\hline & Brachythecium velutinum & $0.51 \pm 0.071$ & $1.69 \pm 0.116$ \\
\hline & Eurhynchium pulchellum & $0.27 \pm 0.044$ & $1.36 \pm 0.066$ \\
\hline \multirow[t]{2}{*}{ Plagiotheciaceae } & Plagiothecium denticulatum & $1.05 \pm 0.160$ & $2.51 \pm 0.282$ \\
\hline & Plagiothecium laetum & $1.70 \pm 0.062$ & $4.01 \pm 0.243$ \\
\hline Climaciaceae & Climacium dendroides & $1.48 \pm 0.030$ & $3.40 \pm 0.086$ \\
\hline \multirow[t]{8}{*}{ Hypnaceae } & Callicladium halandianum & $0.69 \pm 0.187$ & $1.89 \pm 0.246$ \\
\hline & Hypnum curvifolium & $1.29 \pm 0.107$ & $3.03 \pm 0.226$ \\
\hline & Hypnum lindbergii & $0.78 \pm 0.236$ & $2.11 \pm 0.290$ \\
\hline & Hypnum pallescens & $0.96 \pm 0.078$ & $2.77 \pm 0.160$ \\
\hline & Hypnum recurvatum & $0.34 \pm 0.104$ & $1.46 \pm 0.144$ \\
\hline & Ptilium crista-castrensis & $0.27 \pm 0.016$ & $1.42 \pm 0.018$ \\
\hline & Pylaisiella polyantha & $0.37 \pm 0.054$ & $1.43 \pm 0.072$ \\
\hline & Mean & $0.65 \pm 0.038$ & $1.94 \pm 0.065$ \\
\hline \multicolumn{4}{|l|}{ Liverworts } \\
\hline Ptilidiaceae & Ptilidium pulcherrimum & $0.00 \pm 0.000$ & $1.00 \pm 0.000$ \\
\hline Geocalycaceae & Lophocolea heterophylla & $0.09^{*}$ & $1.06^{*}$ \\
\hline Calypogeiaceae & Calypogeia integristipula & $0.12 \pm 0.016$ & $1.12 \pm 0.016$ \\
\hline \multirow[t]{2}{*}{ Jungermanniaceae } & Barbilophozia barbata & $0.01 \pm 0.008$ & $1.08 \pm 0.008$ \\
\hline & Lophozia heterocolpos & $0.06^{*}$ & $1.06^{*}$ \\
\hline \multirow[t]{2}{*}{ Radulaceae } & Radula complanata & $0.02^{* *} \pm 0.008$ & $1.02^{* *} \pm 0.008$ \\
\hline & Mean & $0.043 \pm 0.014$ & $1.04 \pm 0.014$ \\
\hline
\end{tabular}

*Value based on one replicate.

** Mean based on two replicates. 


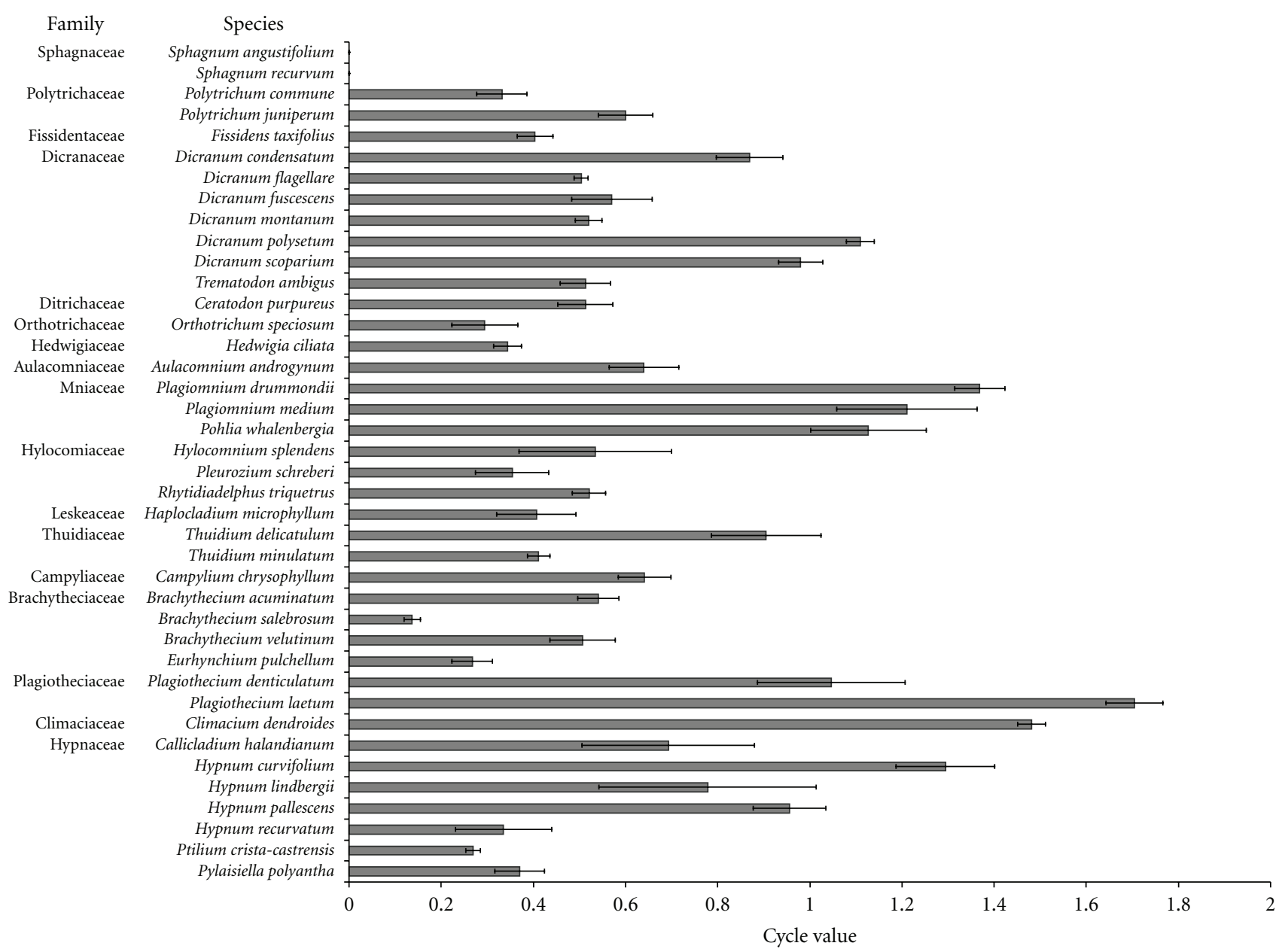

FIGURE 2: Mean cycle value of 40 moss species, determined using flow cytometry. Error bars represent standard error of the mean $(n=3)$.

of endoreduplication cycles per nucleus that occurred in the nuclei measured [8]. As bryophytes are haplophasic, the first endopolyploid level is the $2 \mathrm{C}$ level, which corresponds to one endoreduplication cycle. This is calculated according to the following [16]:

Cycle value

$$
=\frac{\left(0 \times n_{1 c}+1 \times n_{2 c}+2 \times n_{4 c}+3 \times n_{8 c}+4 \times n_{16 c} \cdots\right)}{\left(n_{1 c}+n_{2 c}+n_{4 c}+n_{8 c}+n_{16 c} \cdots\right)} .
$$

Additionally, the mean $C$-level was calculated, which is a measure of the mean ploidy level of the nuclei measured $[10,43]$. This is calculated using the following [16]:

Mean C-level

$$
=\frac{\left(1 \times n_{1 c}+2 \times n_{2 c}+4 \times n_{4 c}+8 \times n_{8 c}+16 \times n_{16 c} \cdots\right)}{\left(n_{1 c}+n_{2 c}+n_{4 c}+n_{8 c}+n_{16 c} \cdots\right)} .
$$

It should be noted that small amounts of nonendopolyploid nuclei can contribute to the number of nuclei in the different ploidy levels. For example, nuclei that were in the
G2 phase of the cell cycle would have a 2C ploidy level, and not necessarily be endoreduplicated nuclei. As well, nuclei can occasionally stick together (forming doublets) and contribute to higher ploidy levels. However, it is expected that in most cases the relative amount of G2 and doublet nuclei will be negligible [16]. Additionally, species with a cycle value less that 0.1 are not considered to be endopolyploid $[8,9]$.

\section{Results}

All moss species measured in this study had distinctly endopolyploid nuclei, with the exception of the Sphagnum mosses (Table 1 and Figure 2). Examples of the flow cytometry results are shown in Figure 3. The average cycle value over all mosses was $0.65 \pm 0.038$ and the mean $C$-level was $1.94 \pm 0.065$. Other than the Sphagnum species, all mosses had $1 \mathrm{C}, 2 \mathrm{C}$ and $4 \mathrm{C}$ nuclei present, and several also had $8 \mathrm{C}$ and 16C nuclei. The bryophyte with the highest degree of endopolyploidy was Plagiothecium laetum, with a mean cycle value of 1.71 and a mean $C$-level of 4.01 (see Figure 3 ).

In contrast, the liverworts we sampled had almost no endopolyploid nuclei (Table 1). The mean cycle value for 


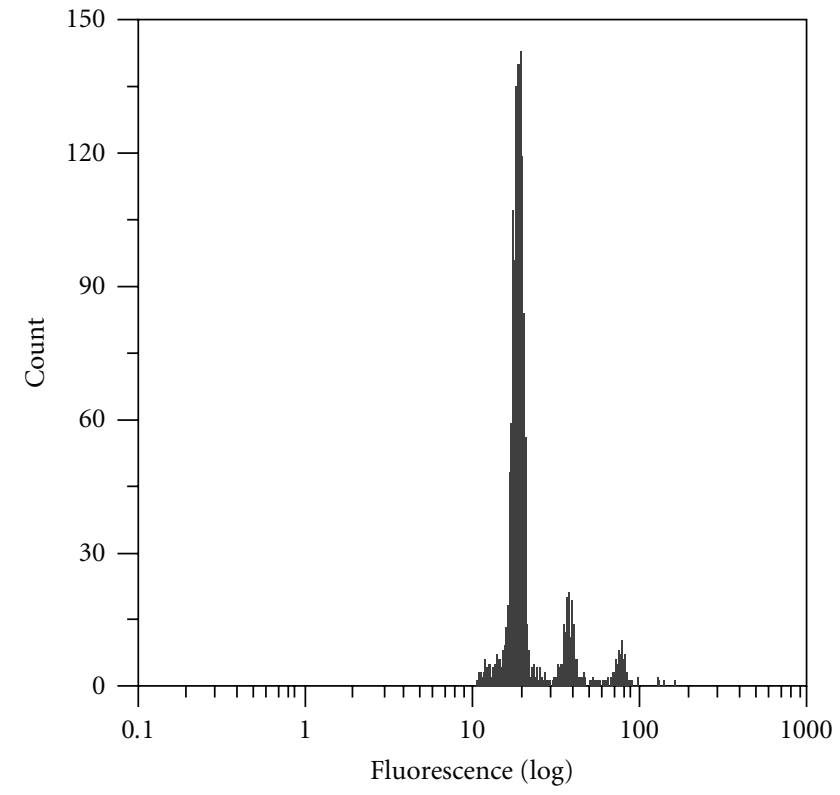

(a)

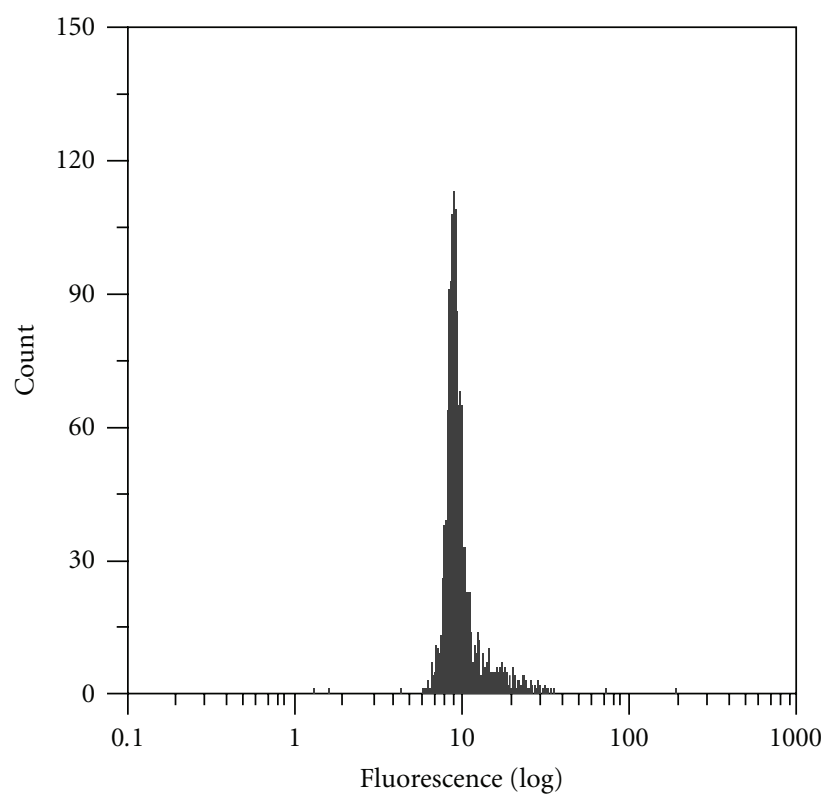

(c)

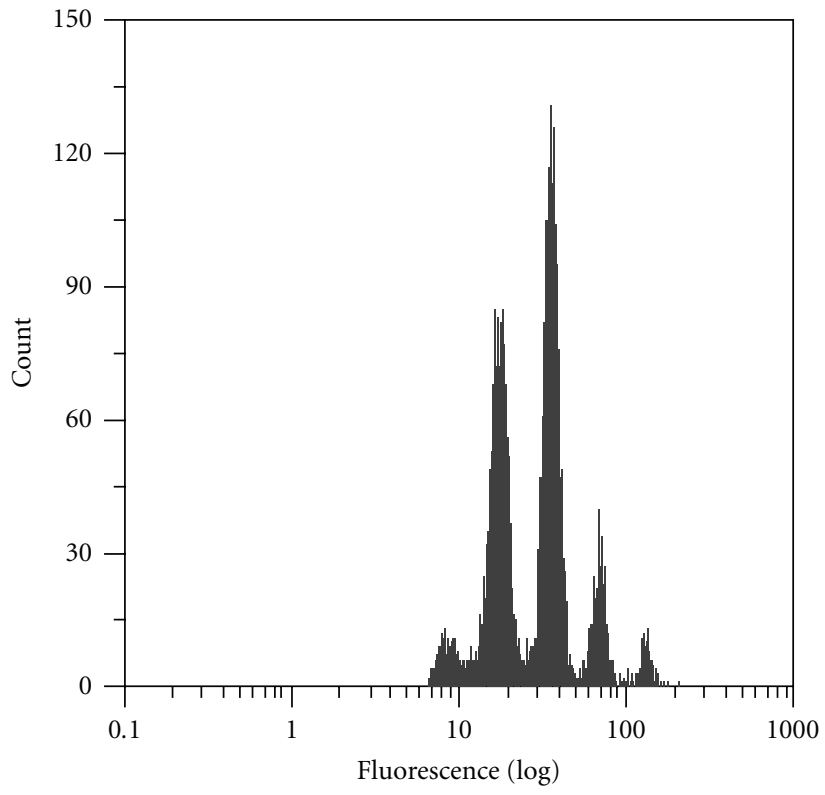

(b)

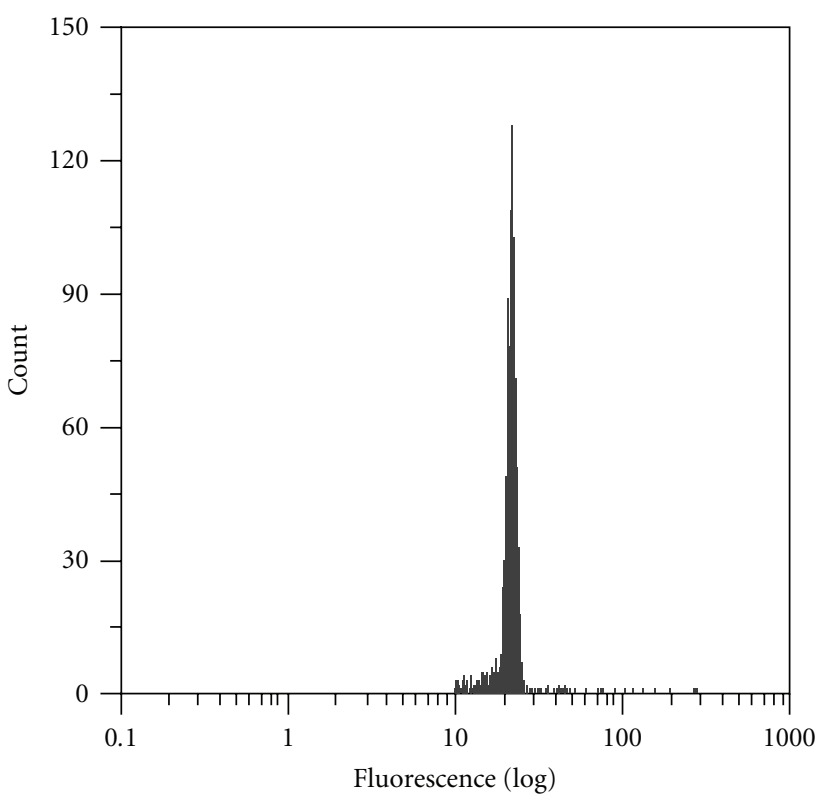

(d)

FIgURE 3: Examples of fluorescence histograms for several species. (a) Brachythecium salebrosum, showing a low degree of endopolyploidization (cycle value $=0.14 \pm 0.018$ ). (b) Plagiothecium laetum, exhibiting the highest degree of endopolyploidization (cycle value $=1.70 \pm 0.062$ ). (c) Sphagnum recurvum, exhibiting no endopolyploidization. (d) Barbilophozia barbata (liverwort), exhibiting no endopolyploidization.

the liverworts was $0.04 \pm 0.014$ and the mean $C$-level was $1.04 \pm 0.014$. Only Calypogeja integristipula had a cycle value over 0.1 , and this was most likely due to the presence of diploid sporophytes in the population, which were difficult to remove at the time of processing. All other species had cycle values below 0.1 , which indicates that if there were nuclei in a second peak, they were likely G2 or doublet nuclei.

\section{Discussion}

Endopolyploidy appears to be widespread in mosses, and absent in liverworts. The species coverage in the current study is not large enough to make conclusions regarding the phylogenetic affiliation of endopolyploidy in bryophytes, however general comments can be made. Some of the moss families analyzed appeared to have a higher incidence of 
endopolyploidy than others, such as the Mniacea. Other families showed considerable variation between species, such as the Dicranaceae and Hypnaceae. The lack of endopolyploidy in the Sphagnaceae could be attributed to the unique occurrence of a large proportion of dead cells (large hyaline cells) to small, green, living cells (chlorophyllose cells) within the leaves [44]. Greater species coverage will allow a more comprehensive view of the prevalence of endopolyploidy in relation to taxonomy.

It is interesting that the liverworts sampled are lacking in endopolyploid nuclei, even though they are closely related to the mosses. Although liverworts have similar life history strategies to mosses, there are considerable biological differences that include: short-lived sporophytes that wither away not long after releasing spores; single-celled rhizoids; the lack of clearly differentiated stem and leaves in thallose species; the presence of deeply lobed or segmented leaves arranged in three ranks; and the presence of oil bodies in at least some of their cells, which are absent from most other bryophytes and from all vascular plants [45]. The disparity in the degree of endopolyploidization between mosses and liverworts could be related to these morphological and biological differences.

From a phylogenetic perspective, as liverworts are sister to all land plants [46] and appear to have a low occurrence of endopolyploid nuclei, endopolyploidy is likely a derived trait. Additionally, the lack of endopolyploidy in Sphagnaceae suggests that the trait evolved after this divergence in bryophytes. Endopolyploidy has likely evolved independently in various groups, as angiosperm families also have varying degrees of endopolyploidy. Future research should involve a broader species coverage across land plants to better understand the phylogenetic implications of endopolyploidy.

As the biological significance of endopolyploidy is just beginning to be explored, there is a considerable amount still to be discovered in relation to bryophyte morphology and environment. It is necessary to determine the cells and tissues responsible for the varying DNA contents, in order to understand the biological role that endopolyploidy plays in bryophyte form and function. Additionally, the environmental impact on endopolyploidization will be especially relevant as bryophytes exhibit habitat specificity. We are currently conducting a more comprehensive survey of the prevalence of endopolyploidy in hepatics, and exploring hypotheses concerning the relative frequency of endopolyploidy (particularly in mosses) in a group of plants that are sister to tracheophytes [46].

As genome size and endopolyploidy appears to be correlated [8], the small genome sizes of mosses [35] and the high degree of endopolyploidy in this group seem to fit this trend. However, this relationship should be explored further, and determination of genome size for the bryophyte species mentioned here is already underway by our research group. Understanding genome size in relation to endopolyploidy and relating DNA content to cell size and function in bryophytes will continue to elucidate the biological significance of endopolyploidy.

\section{Acknowledgments}

The authors would like to thank three anonymous reviewers and Johann Greilhuber for critical review of our manuscript. Many thanks go to Aron J. Fazekas for feedback and consultation and to Jose Maloles, Kelsey O'Brien, and Benjamin Yim for assistance in the field and lab. This work was supported by the National Science and Engineering Research Council of Canada (PGS D to J.D. Bainard; CRD to S.G. Newmaster) and the Canadian Foundation for Innovation (LOF to S.G. Newmaster).

\section{References}

[1] D. Inzé and L. De Veylder, "Cell cycle regulation in plant development," Annual Review of Genetics, vol. 40, pp. 77-105, 2006.

[2] M. D. Bennett, "Perspectives on polyploidy in plants-ancient and neo," Biological Journal of the Linnean Society, vol. 82, no. 4, pp. 411-423, 2004.

[3] H. O. Lee, J. M. Davidson, and R. J. Duronio, "Endoreplication: polyploidy with purpose," Genes and Development, vol. 23, no. 21, pp. 2461-2477, 2009.

[4] L. De Veylder, T. Beeckman, and D. Inzé, "The ins and outs of the plant cell cycle," Nature Reviews Molecular Cell Biology, vol. 8, no. 8, pp. 655-665, 2007.

[5] S. J. Cookson, A. Radziejwoski, and C. Granier, "Cell and leaf size plasticity in Arabidopsis: what is the role of endoreduplication?" Plant, Cell and Environment, vol. 29, no. 7, pp. 12731283, 2006.

[6] M. D. Bennett, "The duration of meiosis," Proceedings of the Royal Society of London Series B, vol. 178, pp. 277-299, 1971.

[7] M. D. Bennett, "Nuclear DNA content and minimum generation time in herbaceous plants," Proceedings of the Royal Society of London. Series B, vol. 181, no. 63, pp. 109-135, 1972.

[8] M. Barow and A. Meister, "Endopolyploidy in seed plants is differently correlated to systematics, organ, life strategy and genome size," Plant, Cell and Environment, vol. 26, no. 4, pp. 571-584, 2003.

[9] G. Jovtchev, V. Schubert, A. Meister, M. Barow, and I. Schubert, "Nuclear DNA content and nuclear and cell volume are positively correlated in angiosperms," Cytogenetic and Genome Research, vol. 114, no. 1, pp. 77-82, 2006.

[10] G. Engelen-Eigles, R. J. Jones, and R. L. Phillips, "DNA endoreduplication in maize endosperm cells: the effect of exposure to short-term high temperature," Plant, Cell and Environment, vol. 23, no. 6, pp. 657-663, 2000.

[11] G. Jovtchev, M. Barow, A. Meister, and I. Schubert, "Impact of environmental and endogenous factors on endopolyploidization in angiosperms," Environmental and Experimental Botany, vol. 60, no. 3, pp. 404-411, 2007.

[12] I. Kinoshita, A. Sanbe, and E.-I. Yokomura, "Difference in light-induced increase in ploidy level and cell size between adaxial and abaxial epidermal pavement cells of Phaseolus vulgaris primary leaves," Journal of Experimental Botany, vol. 59, no. 6, pp. 1419-1430, 2008.

[13] T. L. Setter and B. A. Flannigan, "Water deficit inhibits cell division and expression of transcripts involved in cell proliferation and endoreduplication in maize endosperm," Journal of Experimental Botany, vol. 52, no. 360, pp. 14011408, 2001. 
[14] M. Ceccarelli, E. Santantonio, F. Marmottini, G. N. Amzallag, and P. G. Cionini, "Chromosome endoreduplication as a factor of salt adaptation in Sorghum bicolor," Protoplasma, vol. 227, no. 2-4, pp. 113-118, 2006.

[15] P. W. Barlow, "Endopolyploidy: towards an understanding of its biological significance," Acta Biotheoretica, vol. 27, no. 1-2, pp. 1-18, 1978.

[16] M. Barow and G. Jovtchev, "Endopolyploidy in plants and it analysis by flow cytometry," in Flow Cytometry with Plant Cells, J. Doležel, J. Greilhuber, and J. Suda, Eds., pp. 349-372, WileyVCH, Weinheim, Germany, 2007.

[17] A. G. Garreta, M. A. R. Siguan, N. S. Soler, J. R. Lluch, and D. F. Kapraun, "Fucales (Phaeophyceae) from Spain characterized by large-scale discontinuous nuclear DNA contents consistent with ancestral cryptopolyploidy," Phycologia, vol. 49, no. 1, pp. 64-72, 2010.

[18] D. J. Garbary and B. Clarke, "Intraplant variation in nuclear DNA content in Laminaria saccharina and Alaria esculenta (Phaeophyceae)," Botanica Marina, vol. 45, no. 3, pp. 211-216, 2002.

[19] M. Kwiatkowska, A. Wojtczak, and K. Popłońska, "Effect of GA3 treatment on the number of spermatozoids and endopolyploidy levels of non-generative cells in antheridia of Chara vulgaris L," Plant and Cell Physiology, vol. 39, no. 12, pp. 1388-1390, 1998.

[20] F. D'Amato, "Polyploidy in cell differentiation," Caryologia, vol. 42, pp. 183-211, 1989.

[21] A. Kaźmierczak, "Endoreplication in Anemia phyllitidis coincides with the development of gametophytes and male sex," Physiologia Plantarum, vol. 138, no. 3, pp. 321-328, 2010.

[22] V. S. Polito, "DNA microspectrophotometry of shoot apical meristem cell populations in Ceratopteris thalictroides (Filicales)," American Journal of Botany, vol. 67, pp. 274-277, 1980.

[23] C. R. Partanen, "Comparative microphotometric determinations of deoxyribonucleic acid in normal and tumorous growth of fern prothalli," Cancer Research, vol. 16, pp. 300305, 1956.

[24] R. Ligrone, J. G. Duckett, and K. S. Renzaglia, "Conducting tissues and phyletic relationships of bryophytes," Philosophical Transactions of the Royal Society B, vol. 355, no. 1398, pp. 795$813,2000$.

[25] J. N. Hallet, "Morphogenesis of Polytrichum formosum leafy gametophyte part I. Histochemical histoautoradiographic and cytophotometric studies of the vegetative apex," Annales des Sciences Naturelles Botanique et Biologie Vegetale, vol. 13, pp. 19-118, 1972.

[26] K. I. Kingham, J. G. Duckett, M. C. Glyn, and A. R. Leitch, "Nuclear differentiation in the filamentuos caulonema of the moss Funaria hygrometrica," New Phytologist, vol. 131, no. 4, pp. 543-556, 1995.

[27] B. Knoop, "Multiple DNA contents in the haploid protonema of the moss Funaria hygrometrica sibth," Protoplasma, vol. 94, no. 3-4, pp. 307-314, 1978.

[28] S. Pressel, R. Ligrone, and J. G. Duckett, "Cellular differentiation in moss protonemata: a morphological and experimental study," Annals of Botany, vol. 102, no. 2, pp. 227-245, 2008.

[29] H. Voglmayr, "DNA flow cytometry in non-vascular plants," in Flow Cytometry with Plant Cells, J. Doležel, J. Greilhuber, and J. Suda, Eds., pp. 267-286, Wiley-VCH, Weinheim, Germany, 2007.

[30] A. Hohe, E. Decker, G. Gorr, G. Schween, and R. Reski, "Tight control of growth and cell differentiation in photoautotrophically growing moss (Physcomitrella patens) bioreactor cultures," Plant Cell Reports, vol. 20, no. 12, pp. 1135-1140, 2002.

[31] R. Reski, M. Faust, X.-H. Wang, M. Wehe, and W. O. Abel, "Genome analysis of the moss Physcomitrella patens (Hedw.) B.S.G," Molecular and General Genetics, vol. 244, no. 4, pp. 352-359, 1994.

[32] G. Schween, G. Gorr, A. Hohe, and R. Reski, "Unique tissuespecific cell cycle in Physcomitrella," Plant Biology, vol. 5, no. 1, pp. 50-58, 2003.

[33] G. Schween, J. Schulte, R. Reski, and A. Hohe, "Effect of ploidy level on growth, differentiation, and morphology in Physcomitrella patens," Bryologist, vol. 108, no. 1, pp. 27-35, 2005.

[34] D. L. Nickrent, C. L. Parkinson, J. D. Palmer, and R. J. Duff, "Multigene phylogeny of land plants with special reference to bryophytes and the earliest land plants," Molecular Biology and Evolution, vol. 17, no. 12, pp. 1885-1895, 2000.

[35] H. Voglmayr, "Nuclear DNA amounts in mosses (Musci)," Annals of Botany, vol. 85, no. 4, pp. 531-546, 2000.

[36] B. Goffinet and A. J. Shaw, Bryophyte Biology, Cambridge University Press, Cambridge, UK, 2nd edition, 2009.

[37] A. Vanderpoorten and B. Goffinet, Introduction to Bryophytes, Cambridge University Press, Cambridge, UK, 2009.

[38] S. G. Newmaster, R. J. Belland, A. Arsenault, D. H. Vitt, and T. R. Stephens, "The ones we left behind: comparing plot sampling and floristic habitat sampling for estimating bryophyte diversity," Diversity and Distributions, vol. 11, no. 1, pp. 57-72, 2005.

[39] D. H. Vitt and R. J. Belland, "Attributes of rarity among Alberta mosses: patterns and prediction of species diversity," Bryologist, vol. 100, no. 1, pp. 1-12, 1997.

[40] D. W. Galbraith, K. R. Harkins, and J. M. Maddox, "Rapid flow cytometric analysis of the cell cycle in intact plant tissues," Science, vol. 220, no. 4601, pp. 1049-1051, 1983.

[41] J. Doležel, J. Greilhuber, and J. Suda, "Estimation of nuclear DNA content in plants using flow cytometry," Nature Protocols, vol. 2, no. 9, pp. 2233-2244, 2007.

[42] J. D. Bainard, A. J. F. Fazekas, and S. G. Newmaster, "Methodology significantly affects genome size estimates: quantitative evidence using bryophytes," Cytometry Part A, vol. 77A, no. 4, 2010.

[43] K.-I. Mishiba and M. Mii, "Polysomaty analysis in diploid and tetraploid Portulaca grandiflora," Plant Science, vol. 156, no. 2, pp. 213-219, 2000.

[44] H. Crum, A Focus on Peatlands and Peat Mosses, University of Michigan Press, Ann Arbour, Mich, USA, 1995.

[45] R. M. Schuster, The Hepaticae and Anthocerotae of North America, Field Museum of Natural History, Chicago, Ill, USA, 1992.

[46] Y.-L. Qiu, L. Li, B. Wang et al., "The deepest divergences in land plants inferred from phylogenomic evidence," Proceedings of the National Academy of Sciences of the United States of America, vol. 103, no. 42, pp. 15511-15516, 2006. 

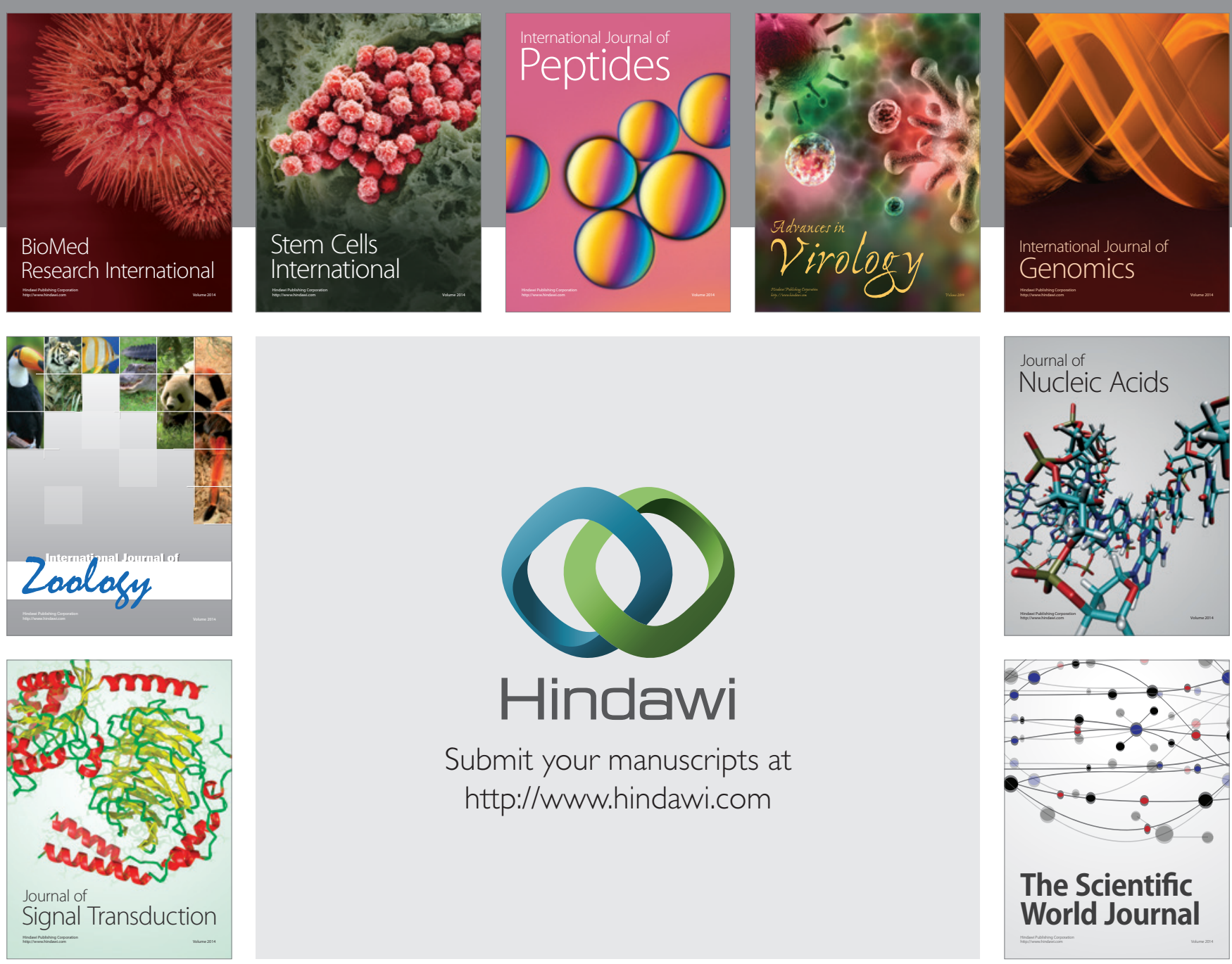

Submit your manuscripts at

http://www.hindawi.com
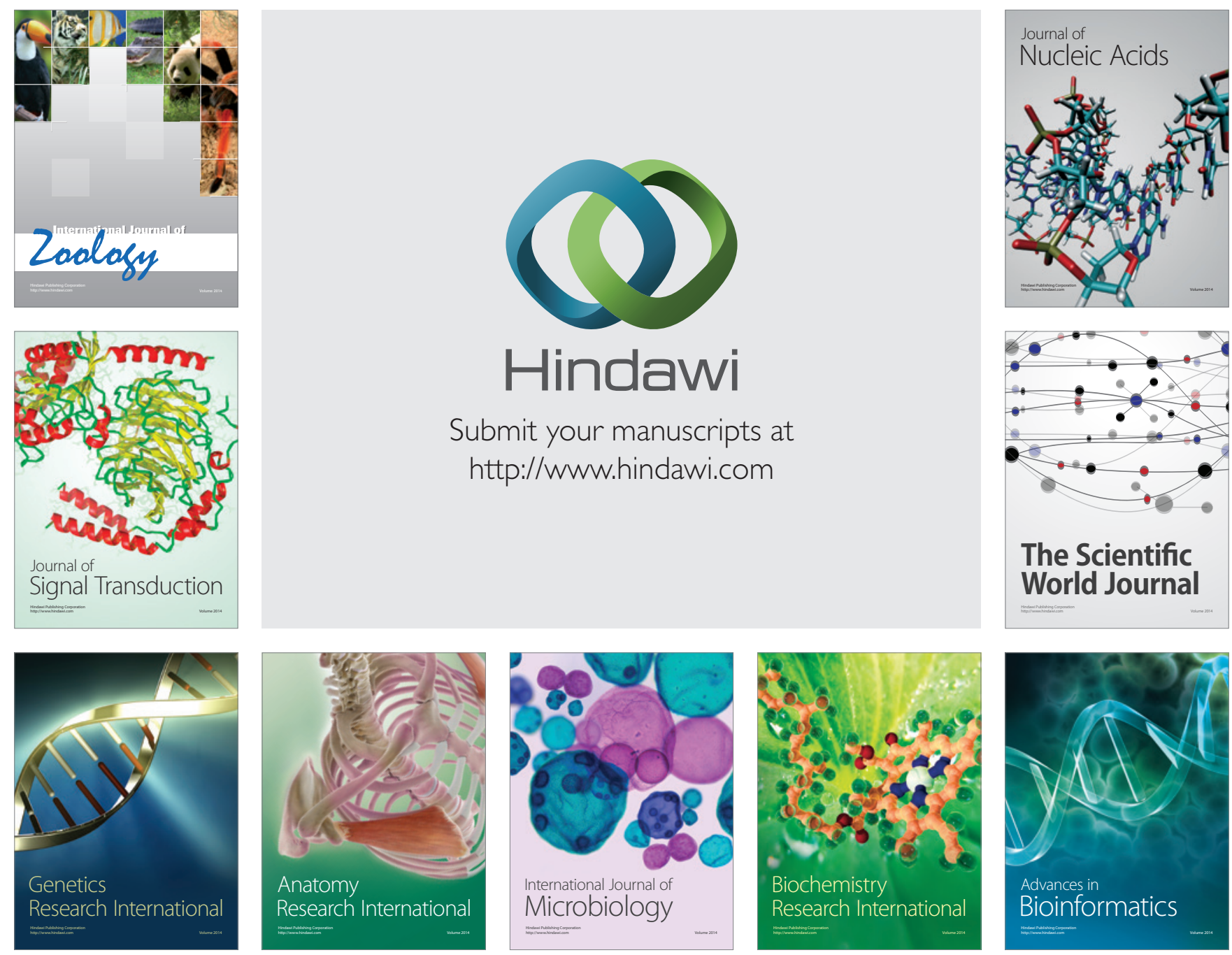

The Scientific World Journal
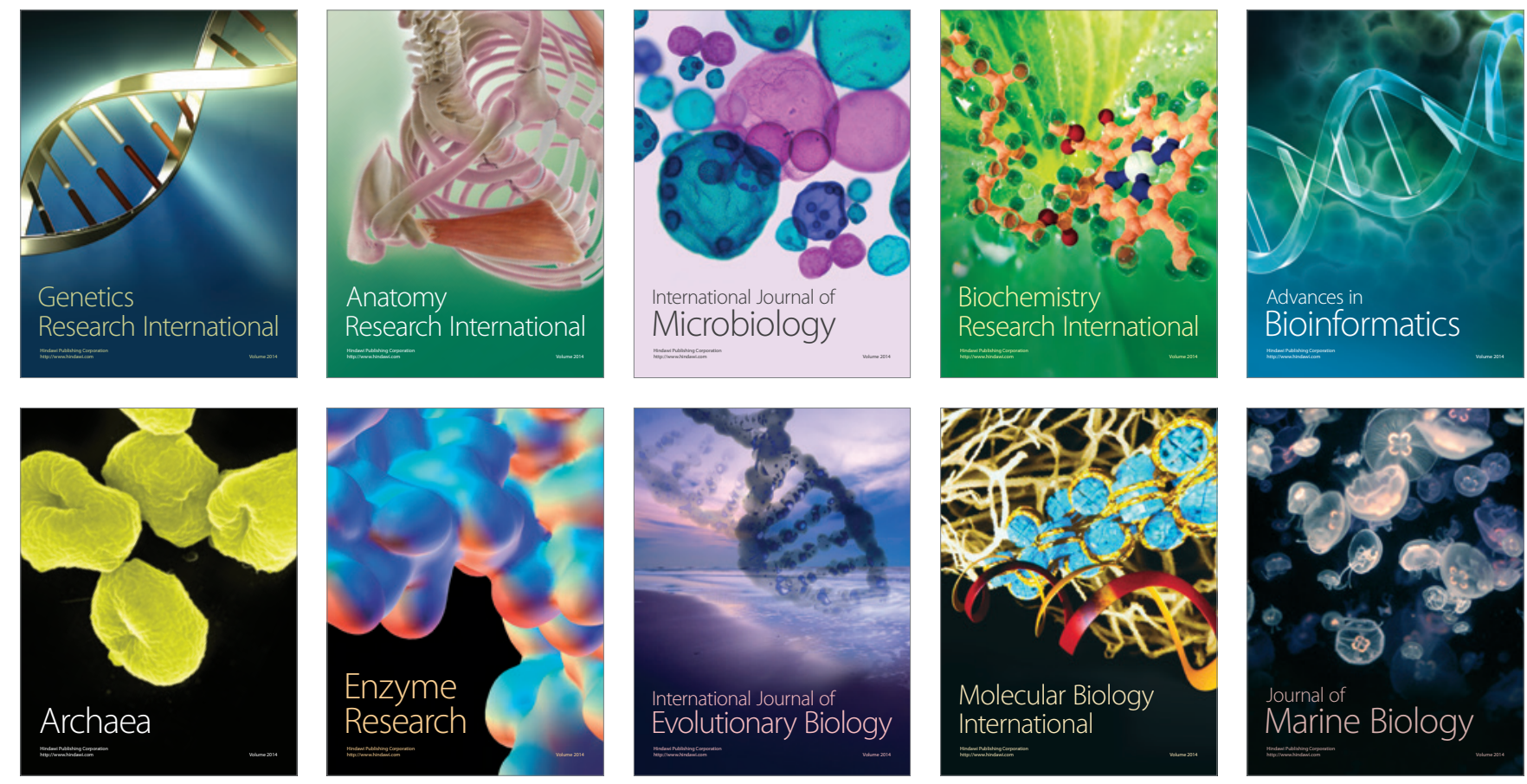